\title{
Public Event: David Barsamian on Corporate Media, Alternative media, and Democracy
}

Time: Wed. November 4, 1.30 p.m.

Location: CMNS Conference Room K8652, Simon Fraser University, Burnaby Campus

\section{Event Summary}

"Information," Jefferson told us, "is the currency of democracy." What is the impact on democracy when currency is owned, printed, packaged and distributed by a handful of megacorporations? Corporate control of media is at unprecedented levels. Bottom-line considerations dumb down the news and narrow the range of opinion. Politically, the powerful broadcasting lobby pretty much gets what it wants. But it is not enough to critique major media. The creation of an independent progressive alternative media is a bromide to the toxic waste produced by mainstream media.

David Barsamian is the award-winning founder and director of Alternative Radio, the independent weekly audio series based in Boulder, Colorado. One of America's most wide-ranging and respected independent journalists, David Barsamian has altered the media landscape with his radio programs and books with Noam Chomsky, Tariq Ali, Howard Zinn, Edward Said, Arundhati Roy, and others. His most recent books are Power Systems with Noam Chomsky and Occupy the Economy with Richard Wolff. He is winner of the Media Education Award, the ACLU's Upton Sinclair Award for independent journalism, the Cultural Freedom Fellowship from the Lannan Foundation, and the 2014 Peacemaker of the Year Award from the Rocky Mountain Peace \& Justice Center. The Institute for Alternative Journalism named him one of its Top Ten Media Heroes.

This event is part of the course CMNS 437, Media Democratization: From critique to transformation. 